\title{
POŠTA
}

TELEKOMUNIKÁCIE A

ELEKTRONICKY OBCHOD

\section{NÁVRH PROJEKTU ROZVOJA SPOLOČNOSTI CBA VEREX, A. S. ZALOŽENÉHO NA ELEKTRONICKOM OBCHODE}

\author{
Mariana Strenitzerová ${ }^{1}$ - Pavol Mikušiak ${ }^{2}$
}

\section{Úvod}

V dnešnej dobe je pre obchodné spoločnosti vel'mi dôležité, aby sa dokázali udržat' na trhu a aby dokázali byt' konkurencieschopné. Obchodná spoločnost' v dnešnom podnikatel'skom prostredí musí robit' všetko preto, aby si aspoň udržala svoje postavenie v tvrdom konkurenčnom boji. Z tohto dôvodu sa vel'a spoločností snaží vypracovat' a dodržiavat' strategický plán, ktorý je zameraný hlavne na uplatňovanie moderných trendov používaných pri podnikaní, na ktorých môže spoločnost' postavit' svoju konkurenčnú výhodu.

V dnešnej dobe sú zákazníci stále náročnejší a pohodlnejší. Ako vel’mi dobre vieme, v celom svete je novým trendom zakladanie rôznych elektronických obchodov. Už hádam ani neexistuje produkt, ktorý by sme na internete nedokázali nájst' a kúpit' cez elektronický obchod. Preto našim hlavným zámerom bolo vypracovat' strategický plán zameraný na implementáciu elektronického obchodu pre vel'koobchodných zákazníkov obchodnej spoločnosti CBA Verex, a. s.. Vieme, že niektoré konkurenčné podniky už takýto elektronický obchod majú, ale stále sú medzi nimi aj také, ktoré sa ešte nerozhodli zaviest' takúto inováciu. Preto si myslíme, že spoločnost' by získala zavedením elektronického obchodu konkurenčnú výhodu voči ostatným spoločnostiam, ktoré sa zatial' elektronický obchod nerozhodli zaradit' do svojho portfólia poskytovaných služieb.

Spoločnost' CBA Verex, a. s. sa nachádza, rovnako ako aj iné spoločnosti, v t’ažkom podnikatel'skom prostredí. V tomto náročnom prostredí je potrebné naučit' sa pracovat'. Nachádza sa v ňom vel'mi vel'a dobrých konkurentov, či už v oblasti vel'koobchodu alebo maloobchodu. V prípade, že spoločnost' chce ostat' nad'alej uznávanou spoločnost'ou v oblasti predaja potravín v oblasti Liptova a Oravy, musí preto niečo urobit'. Je potrebné dobehnút' a možno aj predbehnút' najväčších vel'koobchodných konkurentov. Ak chce spoločnost' CBA Verex, a.s. dobehnút' jej významných konkurentov, musí jednoznačne zaviest' elektronický obchod zo začiatku minimálne pre vel'koobchodných zákazníkov. Tento elektronický obchod by bol určený pre vel'koobchodných zákazníkov spoločnosti CBA Verex, a. s., prostredníctvom ktorého by si mohli objednávat' tovar zo širokého sortimentu produktov. Spoločnost' by prijímala objednávky od svojich zákazníkov a zasielala im pripravený tovar na určené miesto prostredníctvom vlastných dopravných prostriedkov. Zároveň by poskytovala akcie a výhodné ceny len pri nákupe cez elektronický obchod spoločnosti CBA Verex, a. s..

\footnotetext{
${ }^{1}$ doc. Ing. Mariana Strenitzerová, PhD., Žilinská Univerzita v Žiline, Fakulta prevádzky a ekonomiky dopravy a spojov, Katedra spojov, Univerzitná 1, 01026 Žilina, Slovenská republika tel. 00421-041-5133 131, fax 00421-041-5655 615, e-mail: Mariana.Strenitzerova@ fpedas.uniza.sk

2 Ing. Pavol Mikušiak, p.mikusiak@gmail.com
} 


\section{Ciel' projektu a metodika práce}

Našim strategickým zámerom bolo vytvorit' koncepciu, ktorú je vhodné dodržat' pri zavádzaní elektronického obchodu a pomôže spoločnostiam s jeho implementáciou. Koncepcia pozostáva z nasledovných častí: definovanie predmetu elektronického obchodu, definovanie legislatívy, ktorú poskytovatel' elektronického obchodu musí dodržiavat', analyzovanie konkurenčného prostredia, analyzovanie záujmu zákazníkov, vytvorenie webovej aplikácie, ako aj náklady na jej vytvorenie, a v neposlednom rade prognózy do budúcnosti.

Ako z uvedenej jednoduchej koncepcie vyplýva, pre zavedenie elektronického obchodu do spoločnosti je potrebné urobit' vel'mi vel'a krokov ešte pred samotnou implementáciou. Ked’že bez konkurencie to na trhu nejde, bolo potrebné analyzovat' túto oblast'. Rozhodli sme sa analyzovat' najväčších konkurentov vo vel'koobchodnej oblasti. V tejto analýze sme zist'ovali, či majú konkurenčné spoločnosti zavedený elektronický obchod, a ak áno, tak ktoré. Ked’že hlavným ciel'om bolo zavedenie elektronického obchodu, bolo potrebné vykonat' zistenie, či nielen spoločnost' je pripravená na takúto finančne náročnú inováciu a jej implementáciu, ale či sú aj zákazníci spoločnosti ochotní prijat' takýto moderný trend voblasti predaja potravín. Z tohto dôvodu sme vytvorili dotazník, ktorý sme distribuovali určitej skupine vel'koobchodných zákazníkov spoločnosti CBA Verex, a. s.. Na základe výsledkov tohto dotazníka sme mohli skonštatovat', že zákazníci majú záujem o vel'koobchodný predaj potravín prostredníctvom elektronického obchodu spoločnosti CBA Verex, a. s..

Okrem internej a externej analýzy spoločnosti CBA Verex, a. s. a zistenia záujmu o elektronický obchod bolo potrebné taktiež zistit', ktoré zákony je povinný poskytovatel' elektronického obchodu dodržiavat'.

Najdôležitejším bodom, ktorý môže zastavit' každého nádejného obchodníka cez internet, je kalkulácia nákladov na vytvorenie, spustenie a prevádzkovanie elektronického obchodu. Ked'že spoločnost' pred tromi rokmi implementovala nový firemný softvér, rozhodla sa požiadat' tvorcov tohto softvéru o vytvorenie webovej aplikácie elektronického obchodu na základe našich návrhov. Po prekontrolovaní kalkulácie nákladov spojených s tvorbou a prevádzkovaním elektronického obchodu môžeme povedat', že vytvorenie tohto spôsobu predaja vôbec nie je lacné. Myslíme si však, že z dlhodobého hl'adiska môže byt' vytvorenie elektronického obchodu vel'mi užitočné nielen pre zákazníkov, ale aj pre spoločnost' a vynaložené náklady postupne začnú prichádzat' spät'.

\section{Analýza konkurencie z hl'adiska využívania elektronického obchodu}

Medzi najvýznamnejších vel'koobchodných konkurentov v mieste pôsobenia spoločnosti CBA Verex, a. s. patria :

- Metro Cash\&Carry SR, s. r. o.

- Labaš, s. r. o.

- LIBEX, s. r. o.

- INMEDIA, s. r. o.

Na základe konkurenčnej analýzy sme zistili, že všetky spoločnosti majú zavedené elektronické objednávky, čo na prvý pohl'ad vyzerá kriticky, ale v skutočnosti to kritické nie je. Spoločnost' Metro Cash\&Carry SR, s. r. o. a spoločnost' Libex, s. r. o. majú zavedené 
elektronické objednávky a tovar si môžu zákazníci vyzdvihnút' len na určených miestach. To je pre zákazníkov možno na jednej strane pohodlné z dôvodu, že nemusia telefonovat', prípadne tovar objednávat' prostredníctvom emailu a podobne, no na druhej strane to môže byt' pre nich nepohodlné, pretože sa musia dostavit' na určené miesto a tovar si prevziat'. Spoločnost' Labaš, s. r. o. má založený elektronický obchod, ktorý funguje na princípe objednajte si tovar elektronicky a my ho dovezieme priamo k vám. Tento spôsob je ovel'a komfortnejší pre zákazníkov, pretože si tovar môžu objednat' elektronicky, ale nemusia si po tovar íst' na určené miesto. Zákazníci si sami určia, kde chcú mat tovar dovezený a spoločnost' Labaš, s. r. o. im vyhovie. Spoločnost' INMEDIA, s. r. o. má zavedené elektronické objednávanie, ale jej produktový sortiment je výrazne menší ako pri ostatných spoločnostiach.

\section{Záujem vel'koobchodných zákazníkov spoločnosti CBA Verex, a. s. o elektronický obchod}

Za účelom zistenia záujmu zákazníkov spoločnosti CBA Verex, a. s. o elektronický obchod a jeho implementáciu boli oslovení vel'koobchodní zákazníci v celkovom počte 80 . Zákazníkom bol distribuovaný dotazník, v ktorom sa nám okrem iného vyjadrili aj k tomu, či by mali záujem o objednávanie tovaru prostredníctvom tohto komunikačného kanálu. Distribuovaný dotazník pozostával z 10 otázok, z ktorých prvé tri boli identifikačné a zvyšných sedem bolo zameraných na informácie týkajúce sa pripojenia na internet, využívania elektronického obchodu, záujmu o elektronický obchod spoločnosti CBA Verex, a. s., záujmu o poskytovanie iných vernostných programov, formy platby a pod. Návratnost' dotazníka bola 76,25\%.

V nasledujúcej časti sú spracované otázky súvisiace priamo so zavedením elektronického obchodu. Východiskovou otázkou sme chceli zistit', či majú spoločnosti v sídle svojej prevádzky internet. Na základe odpovedí sme zistili, že vel'ká čast' až $64 \%$, čo predstavuje 39 zákazníkov, má v mieste prevádzky internet, a zvyšných 22 zákazníkov internet nemá, ale s jeho zavedením uvažujú.

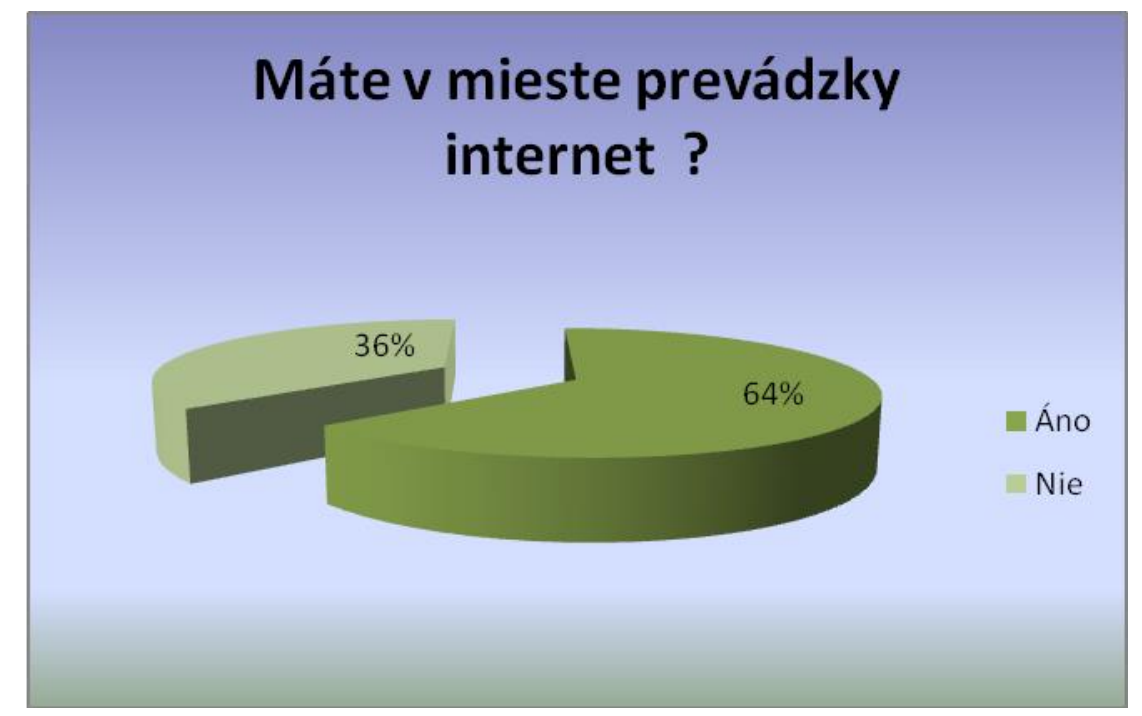

Graf 1. Máte v mieste prevádzky internet ? (vlastné spracovanie) 
Využívali ste alebo využívate nakupovanie cez internet bola naša druhá otázka týkajúca sa zavedenia elektronického obchodu. Na túto otázku sme dostali kladnú odpoved' od 33 opýtaných, čo predstavuje $54 \%$. Zvyšných 28 zákazníkov nezvykne využívat' elektronický obchod nielen s potravinami ale aj s iným spotrebným tovarom.

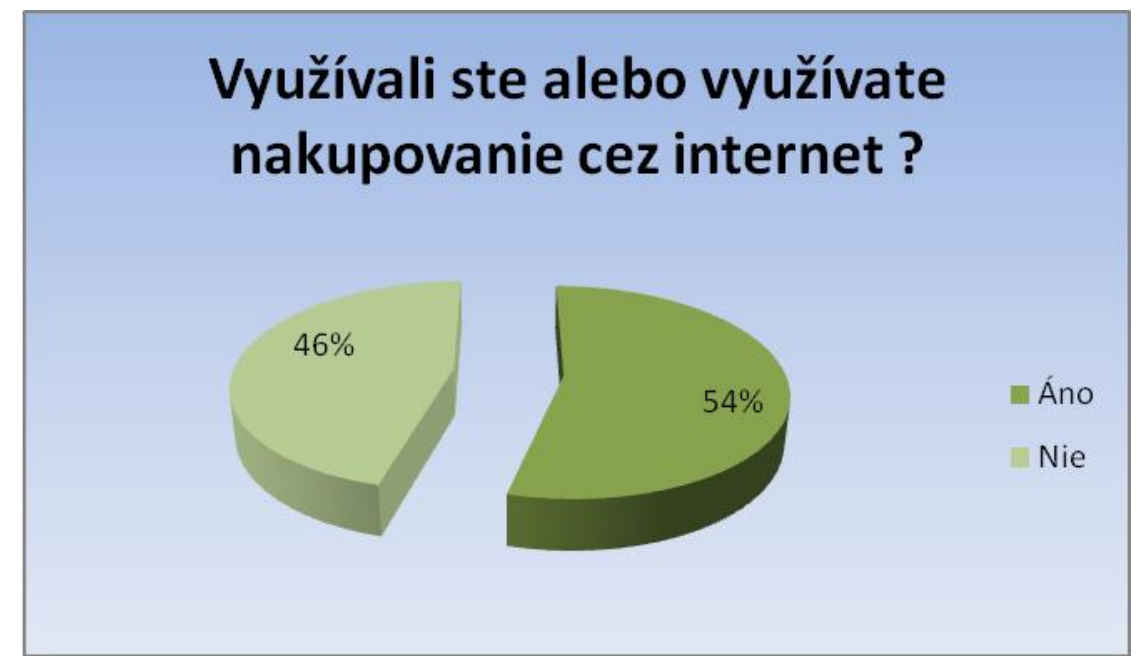

Graf 2. Využívali ste nakupovanie cez internet? (vlastné spracovanie)

Základnou otázkou, a pre nás najdôležitejšou zo všetkých, bola otázka, či by vel'koobchodní zákazníci spoločnosti CBA Verex, a. s. prijali a boli ochotní využívat' elektronický obchod s potravinami. Vel'mi nás potešil záujem zákazníkov a ich odpovede, ked' sme po vyhodnotení dotazníka zistili, že až $74 \%$ opýtaných zákazníkov by bolo ochotných a mali by záujem o vytvorenie elektronického obchodu s potravinami. Sme presvedčení, že napriek tomu, že odpovede na predchádzajúce otázky sa v menšej miere stretli s pozitívnou reakciou, zákazníci sú ochotní sa učit' a prispôsobovat' modernej dobe, a preto by boli schopní vytvorit' si podmienky tak, aby mohli aj oni využívat' elektronický obchod spoločnosti CBA Verex, a. s..

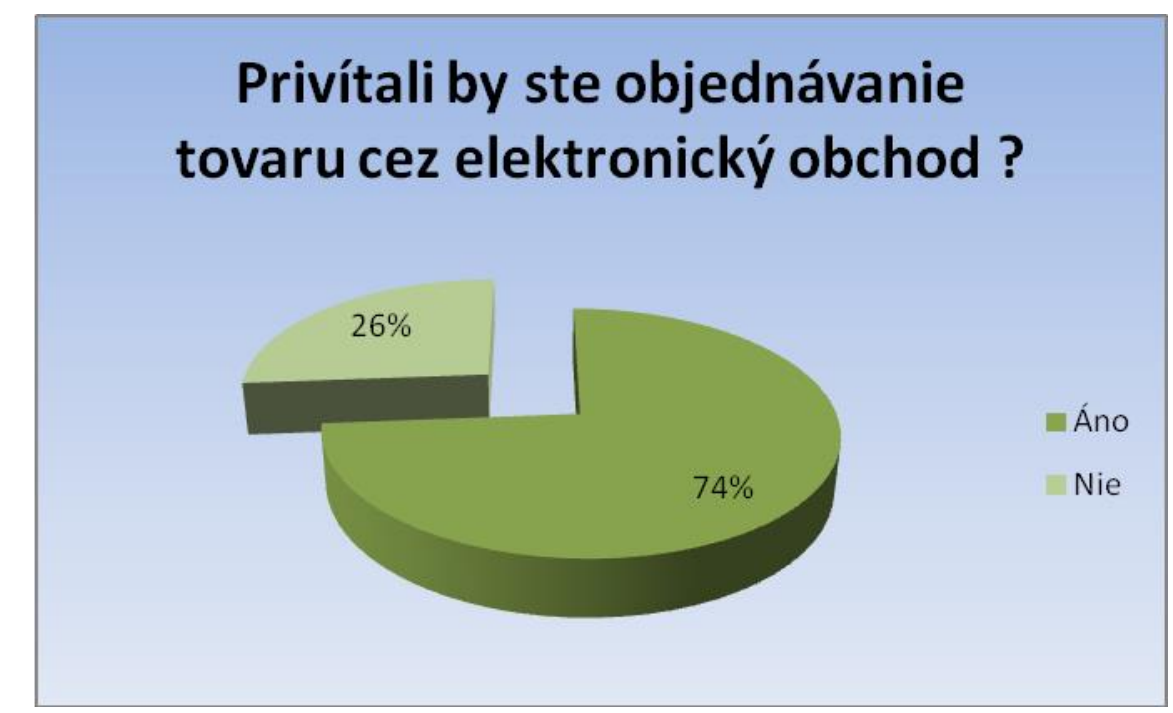

Graf 3. Privítali by ste objednávanie tovaru cez internet ? (vlastné spracovanie) 
Pri zist'ovaní záujmu o poskytovanie vernostných programov sme sa stretli s pozitívnym ohlasom. Až $79 \%$ opýtaných zákazníkov by malo záujem o poskytnutie vernostných programov. Predpokladáme, že každému zákazníkovi sa páčia vernostné programy a výhody s nimi spájané. Preto si myslíme, že by to bolo vel'kou výhodou nielen pre zákazníkov, ale aj pre spoločnost' CBA Verex, a. s..

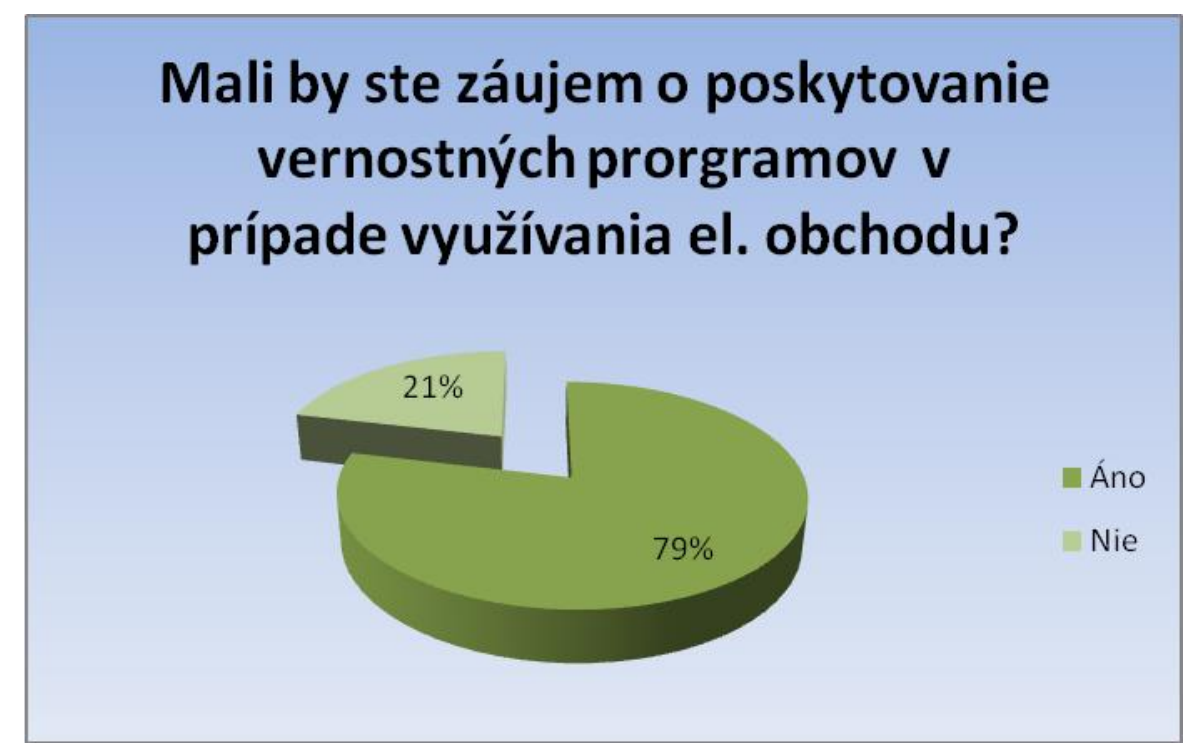

Graf 4. Mali by ste záujem o poskytovanie vernostných programov ? (vlastné spracovanie)

Vel'ký záujem prejavili zákazníci aj o produkty v akciových cenách. Zistili sme, že zo všetkých opýtaných iba jedného tieto produkty nezaujímajú. Percentuálne to môžeme vyjadrit', že až 98 \% vel'koobchodných zákazníkov zaujímajú zl'avené produkty.

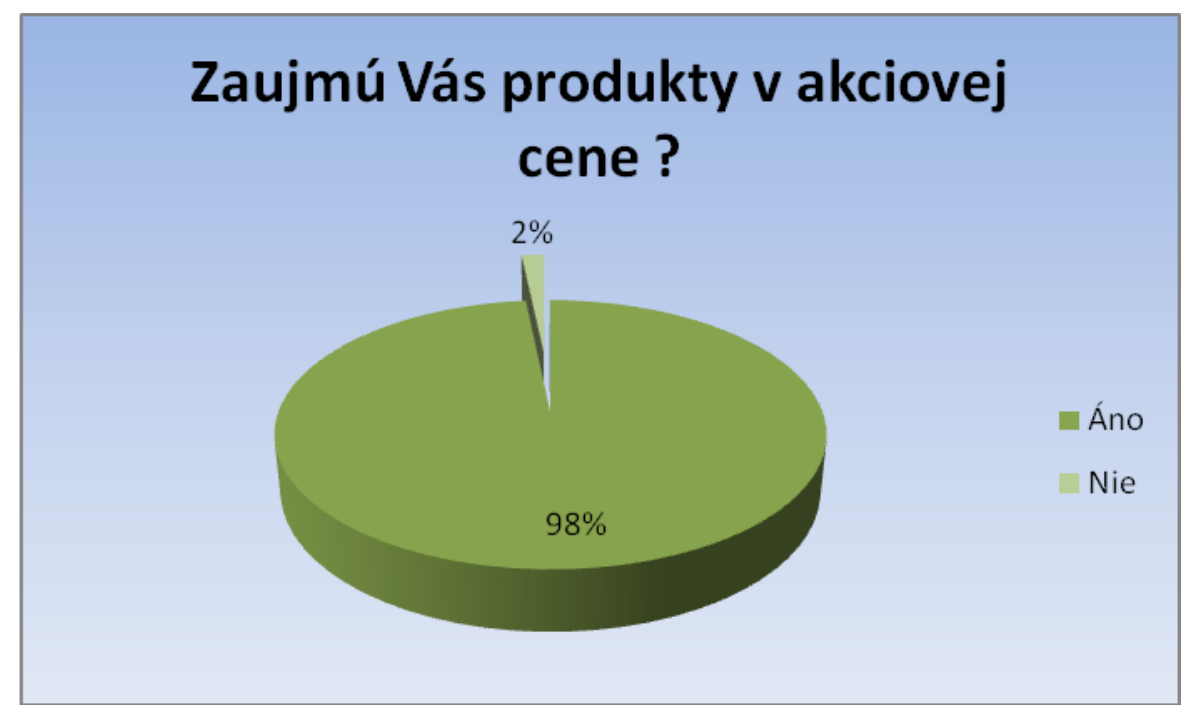

Graf 5. Zaujmú Vás produkty v akciovej cene ? (vlastné spracovanie)

Forma platby je tiež významných faktorom pri využívaní elektronického obchodu. Zistili sme, že odpovede boli takmer vyrovnané, ale predsa len viac zákazníkov by si prialo 
platbu prostredníctvom bankového prevodu, a to až 57 \% opýtaných zákazníkov. Zvyšných $43 \%$ zákazníkov by si prialo platbu prostredníctvom hotovosti pri dodaní tovaru.

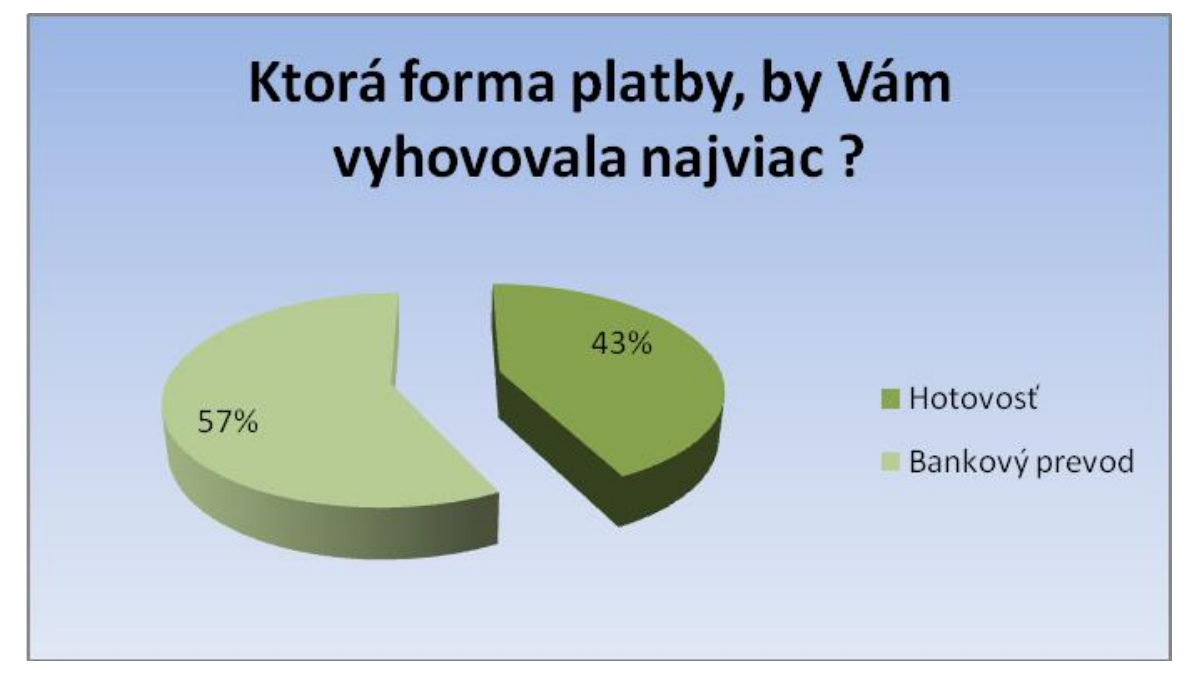

Graf 6. Ktorá forma platby, by Vám vyhovovala najviac? (vlastné spracovanie)

Platba kartou a internet banking sú taktiež obl'úbenou formou platby vel'koobchodných zákazníkov spoločnosti CBA Verex, a. s.. Z vyhodnotenia dotazníkov sme zistili, že až $66 \%$ využíva platbu cez internet a len $34 \%$ nevyužíva takúto platbu. $Z$ tohto dôvodu si myslíme, že zákazníci majú dôveru voči elektronickým platbám a ani spôsob platby prostredníctvom internetu ich nemôže odradit' od nakupovania cez elektronický obchod spoločnosti CBA Verex, a. s..

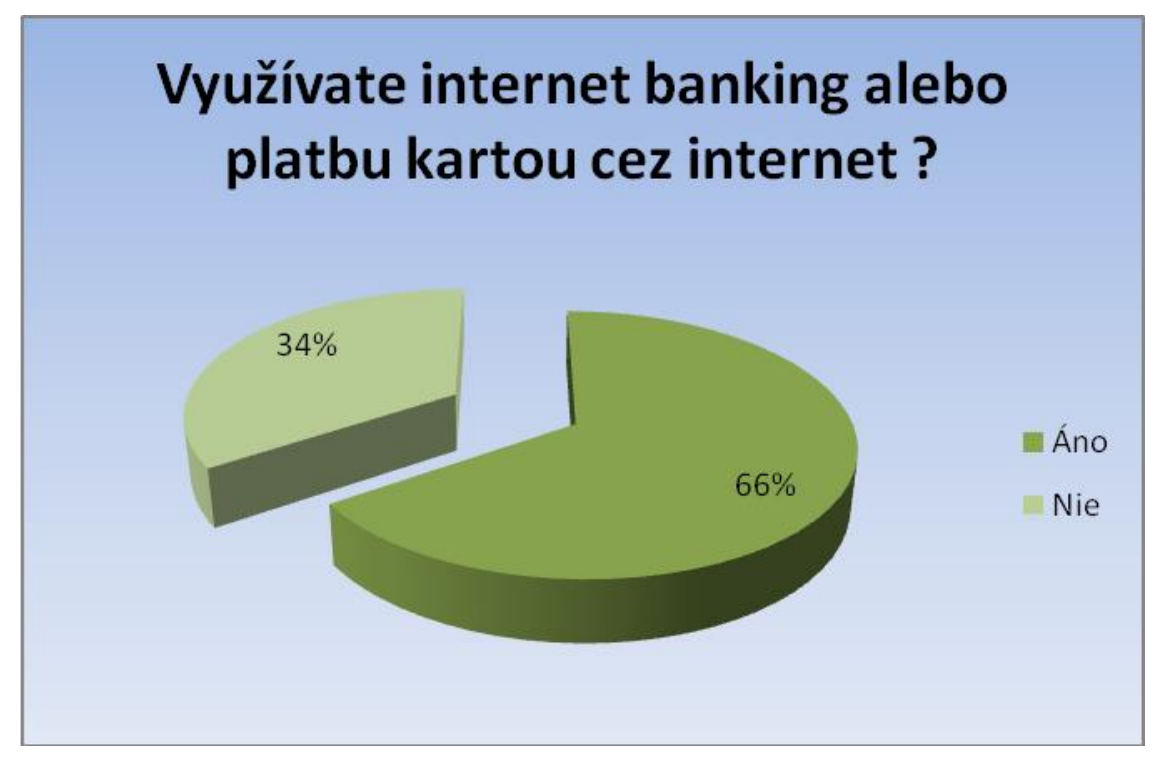

Graf 7. Využívate internet banking alebo platbu kartou cez internet ? (vlastné spracovanie)

\section{Legislatíva upravujúca elektronické obchodovanie}


Vytvorenie elektronického obchodu podlieha rôznym legislatívnym predpisom a zákonom, ktoré musí poskytovatel' elektronického obchodu dodržiavat'. Medzi najdôležitejšie zákony, ktoré musí každá spoločnost' poskytujúca elektronický obchod dodržiavat', patria :

- zákon č. 108/2000 Z.z. o ochrane spotrebitel’a pri podomovom predaji a zásielkovom predaji,

- zákon č. 250/2007 Z.z. o ochrane spotrebitel’a a o zmene zákona Slovenskej národnej rady č. 372/1990 Zb. o priestupkoch v znení neskorších predpisov,

- zákon č. 22/2004 Z.z. o elektronickom obchode a o zmene a doplnení zákona č. 128/2002 Z.z. o štátnej kontrole vnútorného trhu vo veciach ochrany spotrebitel'a a o zmene a doplnení niektorých zákonov v znení zákona č. 284/2002 Z.z.,

- zákon č. 40/1964 Zb. Občiansky zákonník,

- zákon č. 266/2005 o ochrane spotrebitel’a pri finančných službách na dial'ku a o zmene a doplnení niektorých zákonov.

Zároveň musí dodržiavat' :

- úplné a pravdivé informácie o prevádzkovatel'ovi internetového obchodu (IČO a sídlo obchodníka, kontakty na zodpovedné osoby a pod.),

- úplné a pravdivé informácie o tovare resp. službe a cenách vrátane všetkých poplatkov,

- úplné a pravdivé informácie o procese objednávania, dodacích podmienkach a spôsobe vybavenia objednávky (spôsob dodania tovaru resp. služby, cena za dopravu, možnosti platenia a pod.),

- spôsob a podmienky uplatnenia reklamácie tovaru resp. služby,

- spôsob d’alšej komunikácie so zákazníkom (e-mail, telefón...).

V prípade, že by spoločnost' chcela vytvorit' certifikovaný elektronický obchod, musí spíňat' určité pravidlá a musí poskytovat':

- úplné a pravdivé informácie o dodávatel'ovi,

- úplné a pravdivé informácie o tovare,

- úplné a pravdivé informácie o procese objednania a dodacích podmienkach,

- úplné a pravdivé informácie o procese objednávky,

- úplné a pravdivé informácie o záručných podmienkach a reklamácii - uplatnenie práv zo zodpovednosti za škodu,

- zaručenie ochrany osobných údajov spotrebitel'a.

\section{Vytvorenie webovej aplikácie elektronického obchodu}

Elektronický obchod by mal byt' založený ako nový spôsob objednávania tovaru pre vel'koobchodných zákazníkov spoločnosti CBA Verex, a. s.. Ked’že elektronický obchod má byt' implementovaný do existujúcej spoločnosti, nie je potrebné vytvárat' samostatnú právnu formu, a preto elektronický obchod bude vystupovat' pod existujúcou akciovou spoločnost'ou. 
Spoločnost' CBA Verex, a. s. nedávno implementovala nový podnikový softvér, ktorý pre ňu vytvorila spoločnost' NR SYS. Ked’že spoločnost' CBA Verex, a. s. reálne uvažuje nad implementáciou elektronického obchodu, rozhodli sme sa vytvorit' pre nich v spolupráci so spoločnost'ou NR SYS návrh webovej aplikácie pre elektronický obchod, ktorá by spolupracovala s podnikovým softvérom.

Aplikácia bude slúžit' pre registrovaných uživatel'ov systému na tvorbu objednávok. V prípade, že budú mat' zákazníci spoločnosti záujem o registráciu, budú sa musiet' obrátit' na prevádzkovatel'a so žiadost'ou o zriadenie konta, alebo budú musiet' vyplnit' registračný formulár. Prevádzkovatel' na základe žiadosti zriadi prístup do systému s vygenerovaným počiatočným heslom.

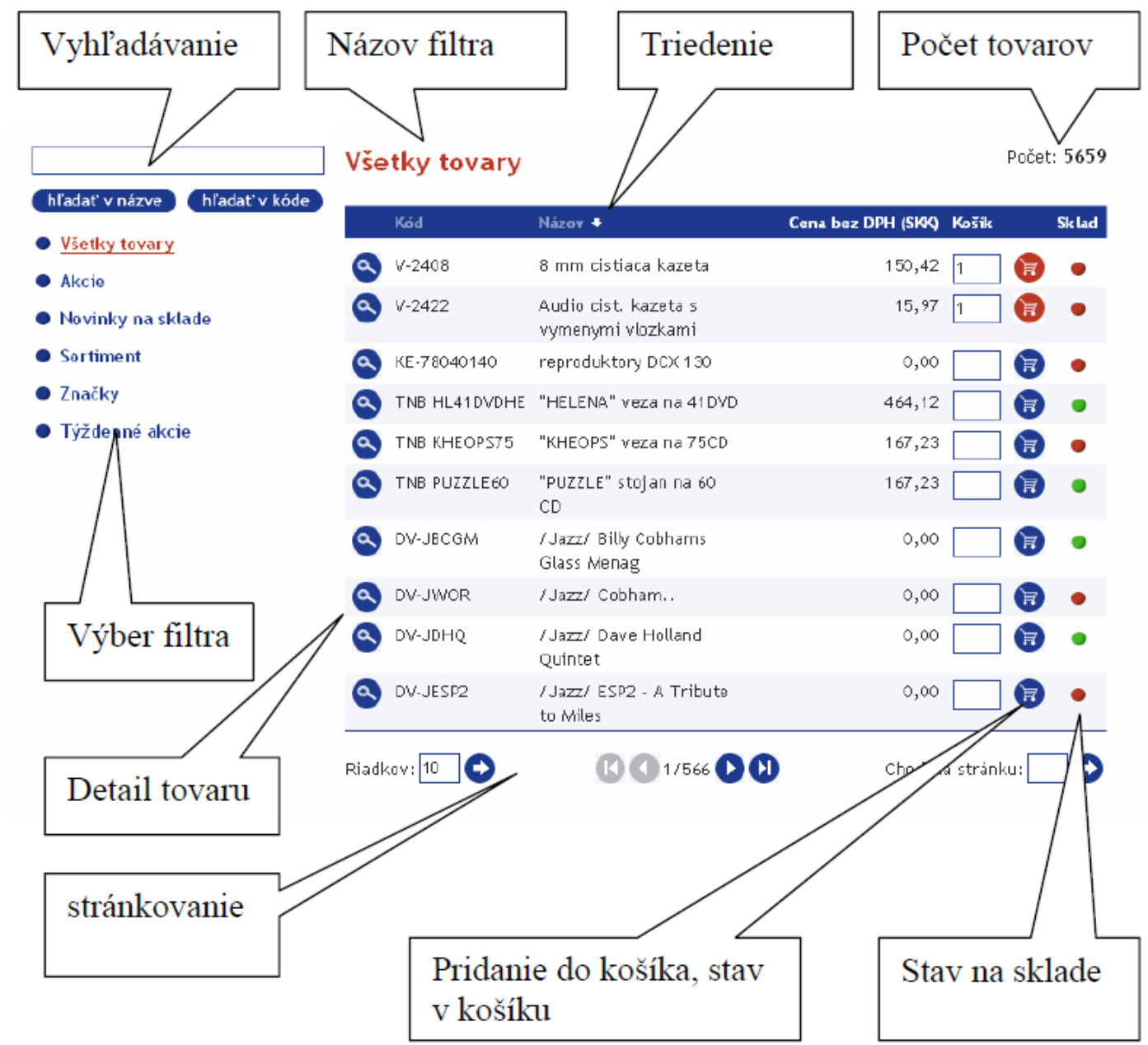

Obrázok 1. Návrh webovej aplikácie Enau (NR SYS)

\section{Rozpočet - Kvantifikácia nákladov vynaložených pred spustením elektronického obchodu}

V nasledujúcej tabul'ke je stručná kalkulácia nákladov na zavedenie a prevádzku elektronického obchodu prostredníctvom webovej aplikácie Enau. Náklady na vytvorenie základnej aplikácie sú vyčíslené do výšky $6000 €$. Ich odhadovaná úprava je kalkulovaná na $5940 €$ a náklady na licenčný ročný upgrade elektronického obchodu je vo výške $720 €$. 


\begin{tabular}{|l|r|r|r|l|l|}
\hline \multicolumn{2}{|c|}{ Kalkulácia nákladov na vytvorenie webovej aplikácie Enau } \\
\hline Názov produktu Nautilus - Elektronická stránka Enau & $\begin{array}{l}\text { Jednotková } \\
\text { cena v EUR }\end{array}$ & 6000 & $\begin{array}{l}\text { Zlava.cena } \\
\text { po zl’ave }\end{array}$ & $\begin{array}{l}\text { Počet } \\
\text { kusov }\end{array}$ & $\begin{array}{l}\text { Celková cena } \\
\text { v EUR }\end{array}$ \\
\hline Elektronický Nautilus cez stránku E-nau & 40 & 7000 & 1 & $6000 €$ \\
\hline Odhadované úpravy & & & & & \\
\hline Licenčný upgrade Nautilus - navýšenie Enau - systém elektronického obchodu & & & & & $5940 €$ \\
\hline Celková suma & & & & & $720 €$ \\
\hline
\end{tabular}

Tabul'ka 1. Kalkulácia nákladov na vytvorenie webovej aplikácie Enau (NR SYS)

\section{Prognózy do budúcnosti}

Hlavnou prognózou do budúcnosti je reálne zavedenie elektronického obchodu pre vel'koobchodných zákazníkov do konca tohto roka. Veríme, že spoločnost' využije vypracovanie tohto projektu ako vhodný návod na dosiahnutie tejto prognózy. Druhou prognózou do budúcnosti je zvýšenie tržieb spoločnosti o $10 \%$. Spoločnost' dosiahla za rok 2011 tržby v celkovej výške $40393620 €$ a zavedením elektronického obchodu by chceli tieto tržby zvýšit' o $10 \%$. Na nasledujúcom grafe môžeme vidiet' prognózu výšky tržieb do roku 2014. Spoločnost' vykazuje od roku 2010 mierny nárast tržieb až do konca roku 2013, kedy má byt' zavedený elektronický obchod. V roku 2014 očakáva spoločnost' zvýšenie tržieb o predpokladaných $10 \%$.

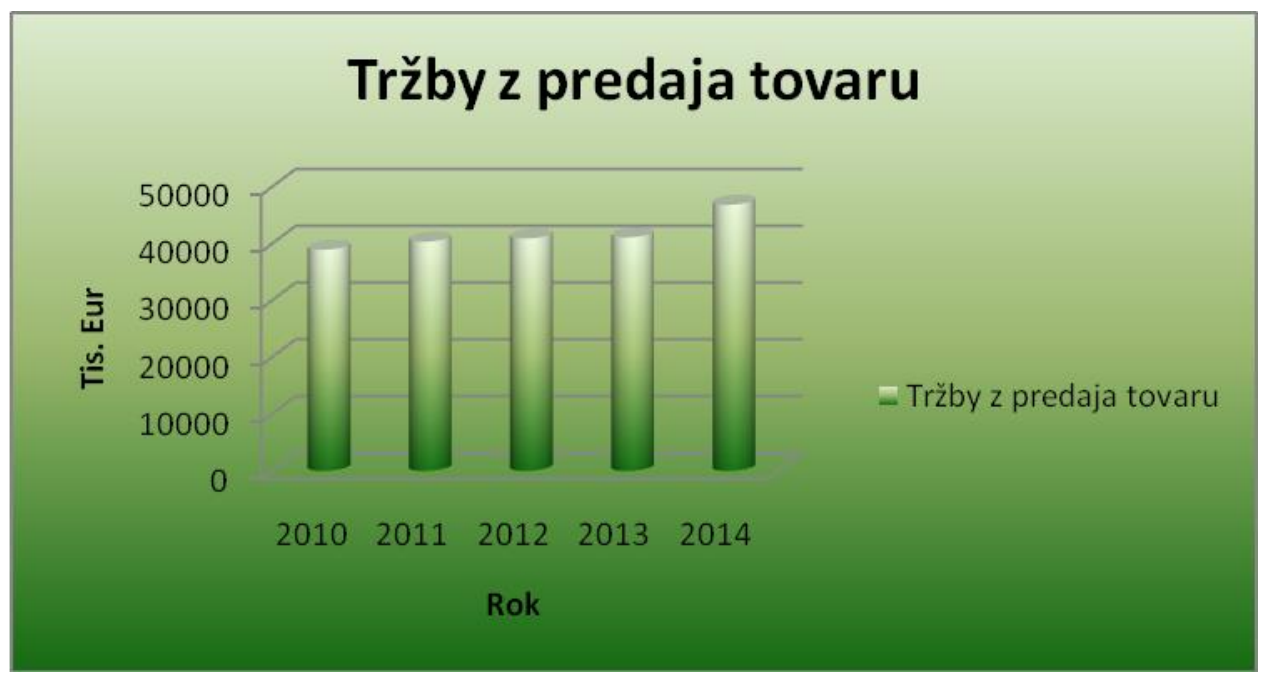

Graf 8. Prognóza vývoja tržieb z predaja do roku 2014 (vlastné spracovanie)

Zavedením elektronického obchodu spoločnost' CBA Verex, a. s. plánuje do budúcnosti získat' 30 \% aktuálnych zákazníkov, ktorí by prešli z bežného objednávania tovaru prostredníctvom telefónu na elektronické objednávanie prostredníctvom webovej aplikácie. V neposlednom rade by chcela spoločnost' získat' nových zákazníkov, ktorých by zaujalo objednávanie tovaru prostredníctvom elektronického obchodu, ako aj získanie zákazníkov, ktorí v minulosti prešli z rôznych dôvodov ku konkurencii.

\section{Záver}


V minulosti len málo inovácií prinieslo tol'ko výhod a prínosov ako elektronický obchod. Globálna podstata technológií, nižšie náklady, široká škála možností a rýchly rast webu predstavujú množstvo výhod pre každého, či už ide o výhody elektronického obchodovania pre spoločnost' alebo pre zákazníkov. Spoločnosti elektronický obchod umožní rozšírenie trhu, nižšie náklady na tvorbu, spracovanie, distribúciu, uskladňovanie a príjem informácií spracovávaných doteraz v papierovej forme, optimalizáciu dodávatel'ského ret’azca, znižovanie komunikačných nákladov, zjednodušenie práce obchodníka, upriamenie na konkrétneho zákazníka, ale aj zlepšenie reputácie spoločnosti, skvalitnenie zákazníckych služieb a zvýšenie flexibility. Elektronický obchod však prináša množstvo výhod aj pre zákazníkov, ako napr. elektronický obchod otvorený 7 dní v týždni 24 hodín, širší sortiment, viac detailov o produkte, možnost' nákupu za nižšie ceny, realizácia rýchleho porovnania cien produktov, ale taktiež zvyšovanie konkurencie prináša zákazníkom zl'avy a výhody. I ked' vstupná investícia do elektronického obchodu môže byt' vysoká, zvýšenie objemu predaja, optimalizácia nákladov, zvýšenie počtu a spokojnosti zákazníkov časom zaručí návratnost' danej investície.

\section{Literatúra}

[1] MIKUŠIAK, P.: Strategický plán rozvoja vybranej organizácie. Diplomová práca. Vedúci diplomovej práce: doc. Ing. Mariana Strenitzerová, PhD., Žilina, 2013

[2] Legislatíva upravujúca elektronické podnikanie. [online]. [cit. 2013-04-22] Dostupné na internete: 〈http://www.bezpecnynakup.sk>

\section{Grantová podpora}

VEGA 1/0421/12 Modelovanie difúzie znalostí v podnikových hodnotových ret'azcoch VEGA 1/0895/13 Výskum strategického riadenia podnikov ako podpora konkurencieschopnosti v dynamickom podnikatel'skom prostredí

Tento článok vznikol v nadväznosti na riešený projekt spolufinancovaný zo zdrojov EÚ s názvom „Kvalita vzdelávania a rozvoj l’udských zdrojov ako piliere vedomostnej spoločnosti na Fakulte PEDAS Žilinskej univerzity v Žiline, ITMS 26110230083.“
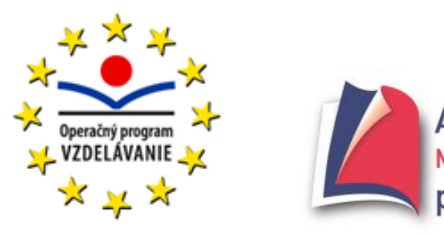

Agentúra

Ministerstva školstva, vedy, výskumu a športu SR pre štrukturálne fondy EÚ

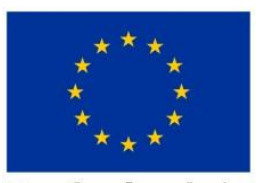

Európsska únia

\section{Moderné vzdelávanie pre vedomostnú spoločnost'/Projekt je spolufinancovaný zo zdrojov EÚ}

